\title{
A Cautionary Tale: Endogenous Biotinylated Proteins and Exogenously-Introduced Protein A Cause Antibody-Independent Artefacts in Western Blot Studies of Brain- Derived Proteins
}

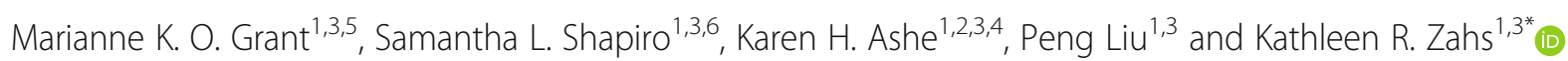

\begin{abstract}
Antibodies are commonly used to detect or isolate proteins from biological samples. Much attention has been paid to the potential for poorly-characterized antibodies to lead to misleading results, but antibody-independent artefacts may also occur. Here, we recount two examples of antibody-independent artefacts that have confounded the interpretation of results in our search for molecular entities associated with memory loss in Alzheimer's disease (AD). First, when using biotin-avidin systems for antibody detection, endogenous biotinylated proteins created spurious bands in Western blots of brain lysates from AD patients and transgenic mouse models of AD. These artefactual bands occurred in a transgene- and strain-dependent manner. A second, unexpected artefact occurred when Protein A-conjugated Sepharose beads were used to deplete lysates of endogenous immunoglobulins prior to immunopurification of target proteins. In these assays, Protein A shed from the beads, then bound to (and was eluted from) an immunoaffinity matrix designed to capture AD-related proteins. The Protein A then bound detection antibodies when the immunoaffinity eluates were analyzed by Western blot. Both of these artefacts-the endogenous biotinylated proteins and the Protein A artefact-can be monitored by including an "irrelevant" antibody as an experimental control (e.g., running a parallel protocol in which the antibody directed against the target of interest is replaced by a non-specific antibody).
\end{abstract}

Keywords: Western blotting, Biotin, Protein A, Artefact

\section{Background}

In 2011-2012, the scientific community was shaken by the publication of two articles from scientists at Bayer Health [1] and Amgen [2], who reported that their attempts to confirm published preclinical findings were successful in only $20-25 \%$ (of 67 ) and $11 \%$ (of 53) of projects, respectively. These papers ignited discussion of a "reproducibility crisis" in science-a discussion that continues to this day in both the scientific and popular

\footnotetext{
* Correspondence: zahsx001@umn.edu

${ }^{1}$ Departments of Neurology, University of Minnesota, Minneapolis, MN 55455, USA

${ }^{3} \mathrm{~N}$. Bud Grossman Center for Memory Research and Care, University of Minnesota, Minneapolis, MN 55455, USA

Full list of author information is available at the end of the article
}

press. A 2016 survey conducted by the journal Nature found that $90 \%$ of the $>1500$ researchers surveyed agreed that there is a reproducibility crisis, with $>70 \%$ reporting that, at one time or other, they were unable to reproduce others' experimental results, and $>50 \%$ reporting that they were unable to reproduce their own results [3]. Several factors have been proposed to contribute to this crisis, including funding and publishing incentives, misuse and/or misunderstanding of statistics, and poor experimental design [4-8]. Unvalidated reagents-particularly antibodies-have received a great deal of attention in the scientific press [9, 10], although, interestingly, reagent quality was not thought to be a major contributor to the lack of reproducibility among respondents in the Nature survey. Greater than $90 \%$ of

(c) The Author(s). 2019 Open Access This article is distributed under the terms of the Creative Commons Attribution 4.0 International License (http://creativecommons.org/licenses/by/4.0/), which permits unrestricted use, distribution, and reproduction in any medium, provided you give appropriate credit to the original author(s) and the source, provide a link to the Creative Commons license, and indicate if changes were made. The Creative Commons Public Domain Dedication waiver (http://creativecommons.org/publicdomain/zero/1.0/) applies to the data made available in this article, unless otherwise stated. 
Nature respondents believed that "more robust experimental design" would lead to greater reproducibility.

Immunocapture and immunoblotting are commonly used to isolate, identify and quantify proteins in biological sample (a PubMed search for "Western blot" conducted on March 14, 2019 returned 310,301 hits). We believe that there has been an unfortunate drift away from robust design in immunoblotting experiments-at least in our field of Alzheimer's disease (AD) research, it does not appear that the use of methodological controls is routine when conducting immunoblotting experiments, despite the calls for more rigorous experimental design. We recently surveyed more than 500 studies (Additional file 1: Figure S1) that employed immunoblotting or immunocapture (immunoprecipitation or immunoaffinity purification) techniques, and found that only 22 of $503(4.4 \%)$ studies reported a methodological control for immunoblotting (e.g., the use of an irrelevant antibody as the primary detection antibody or antigen pre-absorption); methodological controls (e.g., non-specific immunoglobulin for capture) in immunocapture experiments were more common (36 of 81 , or $44 \%$ ), but not universal. The lack of methodological controls can lead to the misinterpretation of experimental results, even when appropriate "sample controls" (e.g., disease vs. healthy control, transgenic vs. non-transgenic animal, drug-treated vs. vehicle-treated animal) are employed.

Here, we recount two examples of artefacts that we have encountered while conducting pilot studies or attempting to reproduce published results. While the first example might have been anticipated based on reports in the literature [11-13], the second was unexpected. In the first case, spurious bands were seen in Western blots when using biotin-avidin systems for antibody detection, due to the presence of endogenous biotinylated proteins. These bands were present in samples from transgenic animals but not non-transgenic controls, and could have easily been misinterpreted in the absence of methodological controls. In the second example, Western blots were used to identify species captured by immunoaffinity purification-here an artefactual band was caused by the introduction of exogenous proteins that were retained during immunoaffinity purification steps and that non-specifically bound (detection) antibodies. In this case, the inclusion of a sample control was sufficient to reveal the artefact, and methodological controls confirmed it.

While these specific illustrations are derived from our studies attempting to identify molecules associated with memory loss in $\mathrm{AD}$, there is the potential for generating comparable artefacts whenever similar techniques are used. It is our hope that these illustrations will serve as a warning to other researchers conducting immunoblotting experiments and will encourage them to incorporate controls that they might have otherwise overlooked.

\section{Methods}

\section{Human Brain Extracts}

Human brain samples were obtained from the Minneapolis Veterans Administration Medical Center. Tissue blocks containing the temporal pole were subjected to a sequential extraction procedure [14]. Tissue was first gently dissociated in buffer 1 (50 mM tris(hydroxymethyl)aminomethane-hydrochloric acid (Tris- $\mathrm{HCl}$ ), $\mathrm{pH}$ 7.6, $0.01 \%$ (volume/volume (v/v)) Nonidet P-40 (NP-40), $150 \mathrm{mM} \mathrm{NaCl}, 2 \mathrm{mM}$ ethylenediaminetetraacetic acid (EDTA), 0.1\% (weight/volume (w/v)) sodium dodecyl sulfate (SDS); with protease and phosphatase inhibitors $(0.1 \mathrm{mM}$ phenylmethylsulfonyl fluoride (PMSF); $0.2 \mathrm{mM}$ 1,10-phenanthroline monohydrate (1,10-PTH); protease inhibitor cocktail (Cat \# P8340, Sigma-Aldrich, St. Louis, MO (currently MilliporeSigma, Burlington, MA)); and phosphatase inhibitor cocktails (Cat \#s P2850 and P5726, Sigma-Aldrich)). The tissue suspension was then centrifuged at $800 \times g$ for $10 \mathrm{~min}$ at $4{ }^{\circ} \mathrm{C}$. The resulting pellet was suspended in buffer $2(50 \mathrm{mM}$ Tris- $\mathrm{HCl}$, $\mathrm{pH} 7.4,150 \mathrm{mM} \mathrm{NaCl}, 0.1 \%$ (v/v) Triton X-100, with protease and phosphatase inhibitors), followed by centrifugation $\left(16,100 \times g, 90 \mathrm{~min}, 4^{\circ} \mathrm{C}\right)$. This pellet was suspended in buffer $3(50 \mathrm{mM}$ Tris-HCl, pH 7.4, $150 \mathrm{mM}$ $\mathrm{NaCl}, 0.5 \%(\mathrm{v} / \mathrm{v})$ Triton X-100, $1 \mathrm{mM}$ EDTA, 3\% (w/v) SDS, $1 \%(\mathrm{w} / \mathrm{v})$ deoxycholate, with protease and phosphatase inhibitors), nutated for $15 \mathrm{~min}\left(4^{\circ} \mathrm{C}\right)$ to further cell lysis, then centrifuged $\left(16,100 \times g, 90 \mathrm{~min}, 4^{\circ} \mathrm{C}\right)$. The resulting supernatant was depleted of endogenous immunoglobulins using Protein-G Fast Flow Sepharose beads (Cat \# 17061801, GE Healthcare Life Sciences, Marlborough, MA; $50 \mu \mathrm{L}$ 1:1 slurry per $0.75-1.0 \mathrm{~mL}$ extract, $\left.1 \mathrm{~h}, 4{ }^{\circ} \mathrm{C}\right)$, then stored at $-20^{\circ} \mathrm{C}$. Protein concentrations were determined immediately before immunoprecipitation/Western blotting, using a bicinchoninic acid (BCA) protein assay kit (Cat \# 23225, Thermo Scientific, Rockford, IL).

\section{Mouse Brain Extracts}

Lysates were prepared from the brains of Tg6209 mice [15] and age-matched, non-transgenic animals, using either the protocol described above (three-step extraction protocol) or an alternative (one-step) protocol. For one-step extraction, each hemi-forebrain was mechanically dissociated in $1 \mathrm{~mL}$ buffer 3 . The resulting homogenate was nutated for $1 \mathrm{~h}\left(4^{\circ} \mathrm{C}\right)$, and then centrifuged $\left(16,100 \times g, 90 \mathrm{~min}, 4^{\circ} \mathrm{C}\right)$. Supernatants were then frozen for at least $24 \mathrm{~h}$, then thawed and centrifuged $(16,100 \times g$, $90 \mathrm{~min}, 4^{\circ} \mathrm{C}$ ). Supernatants from this centrifugation step were depleted of endogenous immunoglobulins using Protein-G Fast Flow Sepharose beads, as described above. Protein concentrations were determined by a BCA protein assay kit (Thermo Scientific). 
Additional lysates were prepared from the brains of hAPP-J20 mice [16] and age-matched, non-transgenic animals, using the three-step protocol described above. The brain extracts using buffer 1 were used for immunoaffinity purification. Lysates were depleted of endogenous immunoglobulins using Fast Flow Sepharose beads conjugated to native Protein A (Cat \# 17528006, GE Healthcare Life Sciences), recombinant Protein A (Cat \# 17127901, GE Healthcare Life Sciences), or Protein G.

\section{Immunoprecipitation (IP)}

Amyloid precursor protein (APP) metabolites were immunoprecipitated from brain lysates using monoclonal antibody 6E10 (Cat \# SIG-39320, Covance, Princeton, NJ (currently Cat \# 803003, BioLegend, San Diego, CA)), which recognizes amino acids $6-10$ of amyloid- $\beta$ $(A \beta)$. Frozen lysates were thawed on ice, then centrifuged at $9600 \times g$ for $20 \mathrm{~min}, 4^{\circ} \mathrm{C}$ to remove any cryoprecipitates. Samples containing $50-100 \mu \mathrm{g}$ protein were brought to a volume of $500 \mu \mathrm{L}$ through the addition of immunoprecipitation dilution buffer (IPDB; $50 \mathrm{mM}$ Tris- $\mathrm{HCl}, 150 \mathrm{mM} \mathrm{NaCl}, \mathrm{pH} 7.4$ ) containing protease and phosphatase inhibitors (0.1 mM PMSF; $0.2 \mathrm{mM}$ 1,10-PTH; protease inhibitor cocktail, and phosphatase inhibitor cocktails, all from Sigma-Aldrich). Samples were then incubated overnight at $4{ }^{\circ} \mathrm{C}$ with $6 \mathrm{E} 10$ capture antibody ( $5 \mu \mathrm{g} /$ reaction) and Protein G-coated magnetic beads (Dynabeads, Cat \# 10004D, Life Technologies, Grand Island, NY (currently Cat \# 10004D, Thermo Fisher Scientific, Waltham, MA); $50 \mu \mathrm{L}$ slurry per reaction). Buffer was then removed, and beads were washed for $20 \mathrm{~min}$ at $4{ }^{\circ} \mathrm{C}$ with immunoprecipitation buffer A (IP buffer A; $50 \mathrm{mM}$ Tris- $\mathrm{HCl}, 300 \mathrm{mM} \mathrm{NaCl}$, $1 \mathrm{mM}$ EDTA, 0.1\% (v/v) Triton X-100, pH 7.4), and then for $20 \mathrm{~min}$ at $4{ }^{\circ} \mathrm{C}$ with immunoprecipitation buffer B (IP buffer B; $50 \mathrm{mM}$ Tris-HCl, $150 \mathrm{mM} \mathrm{NaCl}, 1 \mathrm{mM}$ EDTA, $0.1 \%(\mathrm{v} / \mathrm{v})$ Triton X-100, $\mathrm{pH}$ 7.4). Proteins were eluted by boiling in $30 \mu \mathrm{L}$ SDS- polyacrylamide gel electrophoresis (PAGE) loading buffer (450 mM Tris- $\mathrm{HCl}, \mathrm{pH} 8.0$, $24 \%(\mathrm{v} / \mathrm{v})$ glycerol, $8 \%(\mathrm{w} / \mathrm{v})$ SDS, $0.1 \%(\mathrm{w} / \mathrm{v})$ bromophenol blue, $0.1 \%(\mathrm{v} / \mathrm{v})$ Phenol Red; $5 \%(\mathrm{v} / \mathrm{v}) \beta$-mercaptoethanol).

\section{Preparation of Immunoaffinity Matrices}

Monoclonal antibodies $6 \mathrm{E} 10(200 \mu \mathrm{g})$ or a combination of 13.1.1 and 2.1.3 (anti-A $\beta_{40}$ and anti-A $\beta_{42}$, respectively, $100 \mu \mathrm{g}$ each, gift of Dr. Pritam Das, Mayo Clinic, Jacksonville, FL) were covalently linked to Protein-G coupled magnetic beads $(500 \mu \mathrm{L}$ bead slurry, Protein G Mag Sepharose, Cat \# 28951379, GE Healthcare Life Sciences), according to the following protocol. Beads were washed three times with IPDB containing protease and phosphatase inhibitors $(1 \mathrm{~mL}$ buffer $/ 500 \mu \mathrm{L}$ bead-slurry equivalent), then re-suspended in $1 \mathrm{~mL}$ IPDB with protease inhibitors added (0.1 mM PMSF, $0.2 \mathrm{mM} \mathrm{1,10-PTH,}$ and $1 \times$ protease inhibitor cocktail, Sigma-Aldrich). Antibodies were then added, and the mixture was incubated overnight at $4{ }^{\circ} \mathrm{C}$, with mixing. Buffer with unbound antibody was then removed, and beads were washed one time with $1 \mathrm{~mL}$ IPDB, and one time with $1 \mathrm{~mL}$ triethanolamine (TEA, $200 \mathrm{mM}, \mathrm{pH}$ 9.0). Beads were then incubated for $15 \mathrm{~min}$, room temperature, with mixing, in 1 $\mathrm{mL} 200 \mathrm{mM}$ TEA with $50 \mathrm{mM}$ dimethyl pimelimidate dihydrochloride, in order to crosslink the antibodies to the beads. Following crosslinking, beads were washed once with $1 \mathrm{~mL} 200 \mathrm{mM}$ TEA, $\mathrm{pH} 9.0$, and then the reaction was quenched by incubating the beads in $1 \mathrm{~mL} 10 \%(\mathrm{v} / \mathrm{v})$ ethanolamine, for $15 \mathrm{~min}$ at room temperature, with mixing. The quenching solution was then removed, and the beads were washed once with $100 \mathrm{mM}$ glycine- $\mathrm{HCl}, \mathrm{pH} 2.8$ with $2 \mathrm{M}$ urea, and then three times with IPDB $(1 \mathrm{~mL}$ solution per wash). Beads were stored in $12 \mathrm{~mL}$ IP buffer B with the protease inhibitors listed above, at $4{ }^{\circ} \mathrm{C}$.

\section{Immunoaffinity Purification}

Frozen mouse brain lysates were thawed on ice, and then centrifuged at $9600 \times g$ for $10 \mathrm{~min}, 4^{\circ} \mathrm{C}$ to remove any cryoprecipitates. Lysate (containing $1.5-2 \mathrm{mg}$ protein) was added to the anti-A $\beta_{40 / 42}$ immunoaffinity matrix (with fresh protease inhibitors added), and incubated overnight at $4{ }^{\circ} \mathrm{C}$, with mixing. The buffer was then removed, and the beads were washed with $12 \mathrm{~mL}$ IP buffer B with $1 \%(\mathrm{v} / \mathrm{v})$ Triton $\mathrm{X}-100$. Captured proteins were then eluted using $333 \mu \mathrm{L}$ elution buffer $(33 \mathrm{mM}$ glycine- $\mathrm{HCl}, 1 \%(\mathrm{w} / \mathrm{v})$ Octyl $\beta$-D-1-thioglucopyranoside (Cat \# O6004, Sigma-Aldrich), $\mathrm{pH}$ 2.8). The elution step was repeated two more times.

Additionally, some lysates were subjected to a sequential immunopurification protocol in which lysate was first applied to a 6E10 immunoaffinity matrix, and then the eluate from this matrix was applied to the anti-A $\beta_{40 / 42}$ matrix. Lysate (containing 1.5-2 mg protein) was added to the $6 \mathrm{E} 10$ immunoaffinity matrix (with fresh protease inhibitors added), and incubation, wash, and elutions then proceeded as described above. The three eluates from the $6 \mathrm{E} 10$ matrix were pooled, and protease inhibitors were added. Pooled eluates were concentrated approximately $2 \mathrm{X}$ in a Vacu-fuge, $35 \mu \mathrm{L}$ was removed for Western blotting, and the remaining eluate was applied to the anti- $\mathrm{A} \beta_{40 / 42} \mathrm{immu}$ noaffinity matrix. Incubation, wash, and elutions then proceeded as described above.

\section{Western Blotting (WB)}

Proteins were denatured by boiling for $5 \mathrm{~min}$ in SDS-PAGE loading buffer (note that bromophenol blue was omitted from the loading buffer for blots visualized using the Li-Cor system), then size-fractionated on $10-20 \%$ Tris-Tricine precast gels (Cat \# 345-0067, Bio-Rad, Hercules, CA) and electrophoretically transferred onto 
$0.2-\mu \mathrm{m}$ nitrocellulose membranes at $0.4 \mathrm{~A}$ for $3 \mathrm{~h}$ at $4{ }^{\circ} \mathrm{C}$. Membranes were boiled twice in phosphate-buffered saline (Cat \# P4417-100TAB, Sigma-Aldrich)-for $25 \mathrm{~s}$ and $15 \mathrm{~s}$, with a 4-min interval between periods of boiling, blocked with blocking buffer $(5 \%(\mathrm{w} / \mathrm{v})$ bovine serum albumin (Cat \# A3803-100G, Sigma-Aldrich) in Tris-buffered saline (TBS; $10 \mathrm{mM}$ Tris-HCl, $\mathrm{pH} 7.4,200 \mathrm{mM} \mathrm{NaCl}$ ) with $0.1 \%$ $(\mathrm{v} / \mathrm{v})$ Tween 20 (TBS-T)) for $1 \mathrm{~h}$ at room temperature, and then incubated overnight at $4{ }^{\circ} \mathrm{C}$ with one of the detection antibodies listed in Table 1 (all antibodies were diluted in blocking buffer). Following this overnight incubation, membranes were washed 5 times in TBS-T ( 5 min per wash) at room temperature and further processed according to the detection antibody used.

When biotin-conjugated detection antibodies were used, blots were incubated for 5-10 min at room temperature with Neutravidin-horseradish peroxidase (HRP) (1:5000 in TBS-T, Cat \# A2664, Invitrogen (currently Thermo Fisher Scientific)) or Streptavidin-IRDye 800CW (1:5000; Cat \# $\mathrm{P} / \mathrm{N}$ 926-32,230, Li-Cor, Lincoln, NE), then washed 5 X 5 min in TBS-T. Blots exposed to Neutravidin-HRP were then developed using a chemiluminescence reagent (SuperSignal West Pico Chemiluminescent Substrate, Cat \# 34080, Thermo Fisher Scientific; $4 \mathrm{~min}$, room temperature). Chemiluminescence was detected using Kodak Scientific Imaging film X-OMAT ${ }^{\text {Tn }}$ Blue XB (Cat \# 1776699, Perkin-Elmer Life Sciences Inc., Boston, MA) processed in a Konica medical film processor (Model SRX-101A, Konica Medical Imaging Inc., Wayne, NJ). Blots exposed to Streptavidin-IRDye were washed once with TBS, twice with distilled water, and then imaged using an Odyssey Imaging System (Li-Cor).

When unconjugated 6E10 was used as the detection antibody, membranes were incubated for $1 \mathrm{~h}$ at room temperature in goat-anti-mouse immunoglobulin G (IgG) conjugated to HRP (Cat \# 115-035-174, Jackson
ImmunoResearch, West Grove, PA; 1:200,000 in TBS-T), then washed 5 X 5 min in TBS-T. These blots were developed with chemiluminescence reagent, as described above.

Blots probed with other unconjugated antibodies were incubated for $1 \mathrm{~h}$ at room temperature with the species-appropriate secondary antibody conjugated to an IR dye (goat-anti-mouse IgG conjugated to IRDye $800 \mathrm{CW}, 1: 100,000$; Cat \# P/N 926-32,210; goat-antirabbit IgG conjugated to IRDye 680LT, 1:150,000; Cat \# $\mathrm{P} / \mathrm{N}$ 926-68,021; Li-Cor). Blots were then washed 5 X 5 min in TBS-T, once with TBS, twice with distilled water, and imaged using an Odyssey Imaging System (Li-Cor).

After probing with $6 \mathrm{E} 10$, biotin-conjugated $6 \mathrm{E} 10$ or Neutravidin-HRP, Western blots of brain lysates were stripped using Restore PLUS Western Blot Stripping Buffer (Cat \# 46430, Thermo Scientific) for $1 \mathrm{~h}$ at room temperature. The blots were then washed $5 \times 5 \mathrm{~min}$ in TBS-T, blocked with blocking buffer for $1 \mathrm{~h}$ at room temperature, and then incubated overnight at $4{ }^{\circ} \mathrm{C}$ with anti- $\alpha$-tubulin, $5 \mathrm{ng} / \mathrm{mL}$ blocking buffer. Subsequently, membranes were incubated for $1 \mathrm{~h}$ at room temperature in goat-anti-mouse IgG conjugated to HRP, then washed $5 \mathrm{X} 5 \mathrm{~min}$ in TBS-T. These blots were developed with chemiluminescence reagent, as described above.

\section{Results \\ Spurious Bands in Western Blots Due to the Presence of Endogenous Biotinylated Proteins}

The first artefact was revealed when we were attempting to identify amyloid precursor protein (APP) metabolites in the brains of transgenic mice that express human APP. (APP transgenic mice are used to model amyloid-related processes in $\operatorname{AD}[17,18])$. As a first step, biotin-conjugated monoclonal antibody $6 \mathrm{E} 10$ was used

Table 1 Antibodies

\begin{tabular}{|c|c|c|c|c|}
\hline Antibody & Format & Isotype & Vendor & Product Number \\
\hline Anti-A $\beta_{40}$ & Affinity-purified monoclonal & Mouse lgG1, k & Gift of Dr. Pritam Das & 13.1 .1 \\
\hline Anti-A $\beta_{42}$ & Affinity-purified monoclonal & Mouse lgG1, k & Gift of Dr. Pritam Das & 2.1 .3 \\
\hline Anti-APP(C-terminal) & Affinity-purified monoclonal & Rabbit IgG & Invitrogen ${ }^{a}$ & $36-6900$ \\
\hline 1G6-biotin & Affinity-purified monoclonal & Mouse lgG2b & Covance $^{b}$ & SIG-39181 \\
\hline $4 G 8$ & Affinity-purified monoclonal & Mouse IgG2b, k & Covance $^{b}$ & SIG-39220 \\
\hline $6 \mathrm{E} 10$ & Affinity-purified monoclonal & Mouse IgG1 & Covance $^{b}$ & SIG-39320 \\
\hline 6E10-biotin & Affinity-purified monoclonal & Mouse lgG1 & Covance $^{b}$ & SIG-39340 \\
\hline 82E1-biotin & Affinity-purified monoclonal & Mouse lgG1 & IBL America (Minneapolis, MN) & 10,326 \\
\hline A11 & Rabbit serum & $N A^{c}$ & Gift of Dr. Charles Glabe & \\
\hline $22 \mathrm{C} 11$ & Affinity-purified monoclonal & Mouse IgG1 & EMD Millipore $^{d}$ & MAB348 \\
\hline Anti-Protein A-biotin & Affinity-purified monoclonal & Mouse lgG1 & Sigma-Aldrich $^{d}$ & B-3150 \\
\hline Anti-a-tubulin & Affinity-purified monoclonal & Mouse IgG1 & Sigma-Aldrich $^{\mathrm{d}}$ & $\mathrm{T}-5168$ \\
\hline
\end{tabular}

${ }^{a}$ now Thermo Fisher Scientific (Waltham, MA); ${ }^{b}$ now Biolegend (San Diego, CA); ${ }^{c} \mathrm{NA}=$ not applicable; ${ }^{\mathrm{d}}$ now MilliporeSigma (Burlington, MA) 
to probe Western blots of brain lysates from Tg6209 APP transgenic mice; brain lysates from age-matched, non-transgenic mice were used as negative controls. $6 \mathrm{E} 10$ is a commonly-used antibody that recognizes amino acids 677-681 (amino acid position in 770-amino acid isoform, Uniprot P05067; corresponds to amino acids 6-10 of A $\beta$ ) of human, but not mouse, APP [19]. The biotin-conjugated antibody was used in order to amplify any signals and increase the likelihood of detecting low-abundance APP metabolites. Bound antibody was detected by incubation of the blots with Neutravidin conjugated to HRP, followed by chemiluminescence reagent (peroxidase substrate). Three prominent bands, at approximately $22 \mathrm{kDa}, 75 \mathrm{kDa}$ and $150 \mathrm{kDa}$, were seen in samples from both transgenic and non-transgenic animals, and were immediately regarded as non-specific (in our experience, $\sim 75 \mathrm{kDa}$ and $\sim 150 \mathrm{kDa}$ bands are seen whenever an avidin derivative is used to probe blots of mouse brain lysates, regardless of the detection antibody employed). Several bands were present in transgenepositive $\operatorname{Tg} 6209$ mice, but absent in non-transgenic controls: a band at $\sim 100 \mathrm{kDa}$ (molecular weight of full-length APP or $\mathrm{SAPP} \alpha$, the soluble product formed by proteolytic cleavage of APP by $\alpha$-secretase) and multiple additional bands at approximate molecular weights of $62 \mathrm{kDa}, 55 \mathrm{kDa}, 46 \mathrm{kDa}, 25 \mathrm{kDa}$, and $15 \mathrm{kDa}$, which we suspected might represent SDS-stable $A \beta$ oligomers or other APP metabolites (Fig. 1a). However, the bands at $\sim 55 \mathrm{kDa}$ and $\sim 46 \mathrm{kDa}$ were not immunoprecipitated by antibody $6 \mathrm{E} 10$, calling into question the identity of these bands as genuine 6E10-immunoreactive species. (Immunoprecipitation weakened, but did not eliminate, the non-specific bands at $\sim 75 \mathrm{kDa}$ and $\sim 150 \mathrm{kDa}$, indicating that our wash conditions were not stringent enough to fully remove these highly abundant and/or "sticky" species). Indeed, the transgene-dependent $\sim 46$ $\mathrm{kDa}$ and $\sim 55 \mathrm{kDa}$ bands, as well as the $\sim 75 \mathrm{kDa}$ and $\sim$ $150 \mathrm{kDa}$ bands, were present when blots were exposed only to Neutravidin-HRP followed by chemiluminescence reagent (Fig. 1b), indicating that these bands represented species that reacted either with the Neutravidin (i.e., endogenous biotinylated proteins) or with the chemiluminescence reagent (i.e., endogenous peroxidases whose activity survived detergent extraction and SDS-PAGE). We concluded that the $\sim 46 \mathrm{kDa}$ and $\sim 55$ $\mathrm{kDa}$ bands seen in Western blots of Tg6209 lysates were transgene-dependent, antibody-independent artefacts caused by the detection protocol. Had we only performed Western blots using a sample control, we could have erroneously concluded that these bands represented actual APP metabolites. The failure to immunoprecipitate these bands aroused suspicion, but in the absence of further experiments, might have been attributed to epitope masking under native conditions.
Similar artefacts were also found to be present in human samples. In blots of lysates from AD patients, we observed bands at $\sim 4.5 \mathrm{kDa}$ (the molecular weight of $\mathrm{A} \beta$ monomers), $\sim 100 \mathrm{kDa}$, and multiple additional, distinct bands at approximately $62 \mathrm{kDa}, 55 \mathrm{kDa}, 37-45 \mathrm{kDa}$, and $12-25 \mathrm{kDa}$ (Fig. 1c). The non-specific bands at $\sim 75 \mathrm{kDa}$ and $\sim 150 \mathrm{kDa}$ were also observed in blots of human samples. As was the case for the mouse samples, several of these bands were not immunoprecipitated by $6 \mathrm{E} 10$ (i.e., bands $\sim 55 \mathrm{kDa}, 37-45 \mathrm{kDa}$, and 15-25 kDa) (Fig. 1d), and these same bands persisted when biotin-conjugated 6E10 was omitted from the Western blotting protocol (Fig. 1e), indicating that these bands represented species that reacted either with the Neutravidin or with the chemiluminescence reagent. Conversely, the $\sim 4.5 \mathrm{kDa}$ band, a doublet of bands at $\sim 12 \mathrm{kDa}$, and the heavy band at $~$ $100 \mathrm{kDa}$ were immunoprecipitated by $6 \mathrm{E} 10$ and were absent from blots exposed only to Neutravidin-HRP and chemiluminescence reagent, supporting their identity as genuine 6E10-immunoreactive species (Fig. 1d and e). (The $\sim 62-\mathrm{kDa}$ band was difficult to distinguish after immunoprecipitation-it appeared to be present, but was largely obscured in "smears" in the region of $~ 55-75$ $\mathrm{kDa}$ ). When blots were exposed to chemiluminescence reagent without Neutravidin-HRP (i.e., blots were probed using unconjugated 6E10 followed by goat-anti-mouse IgG-HRP secondary antibody; Fig. 1f), the bands seen in Fig. 1e failed to appear, strongly suggesting that these bands represent endogenous biotinylated molecules. Unfortunately, without the signal amplification provided by the biotin-avidin detection system, the $\sim 4.5-\mathrm{kDa}$ (likely monomeric $\mathrm{A} \beta$ ) and $\sim 12-\mathrm{kDa}$ bands were not detectable in blots probed using $6 \mathrm{E} 10 /$ secondary antibody-HRP even at an exposure time (i.e., $1 \mathrm{~h}$ ) when the signal intensity was maximal using this detection system. In order to avoid the detection of endogenous biotinylated proteins, while taking advantage of the amplification afforded by a biotin-avidin detection system, we recommend that target proteins be immunoprecipitated prior to Western blotting (as shown in Fig. 1a (right) and 1d).

\section{Introduction of Exogenous Proteins that Non-specifically Bind Detection Antibodies}

As part of our standard protocol for the preparation of brain lysates, we deplete the lysates of endogenous immunoglobulins using either Protein A or Protein G conjugated to Sepharose beads. This depletion step serves to eliminate mouse immunoglobulins that: i) would be detected when anti-mouse secondary antibodies are used in subsequent immunoblotting experiments, and ii) might bind to Protein A or Protein G in immunoprecipitation experiments. Surprisingly, this depletion step led to a conspicuous and potentially very misleading artefact 


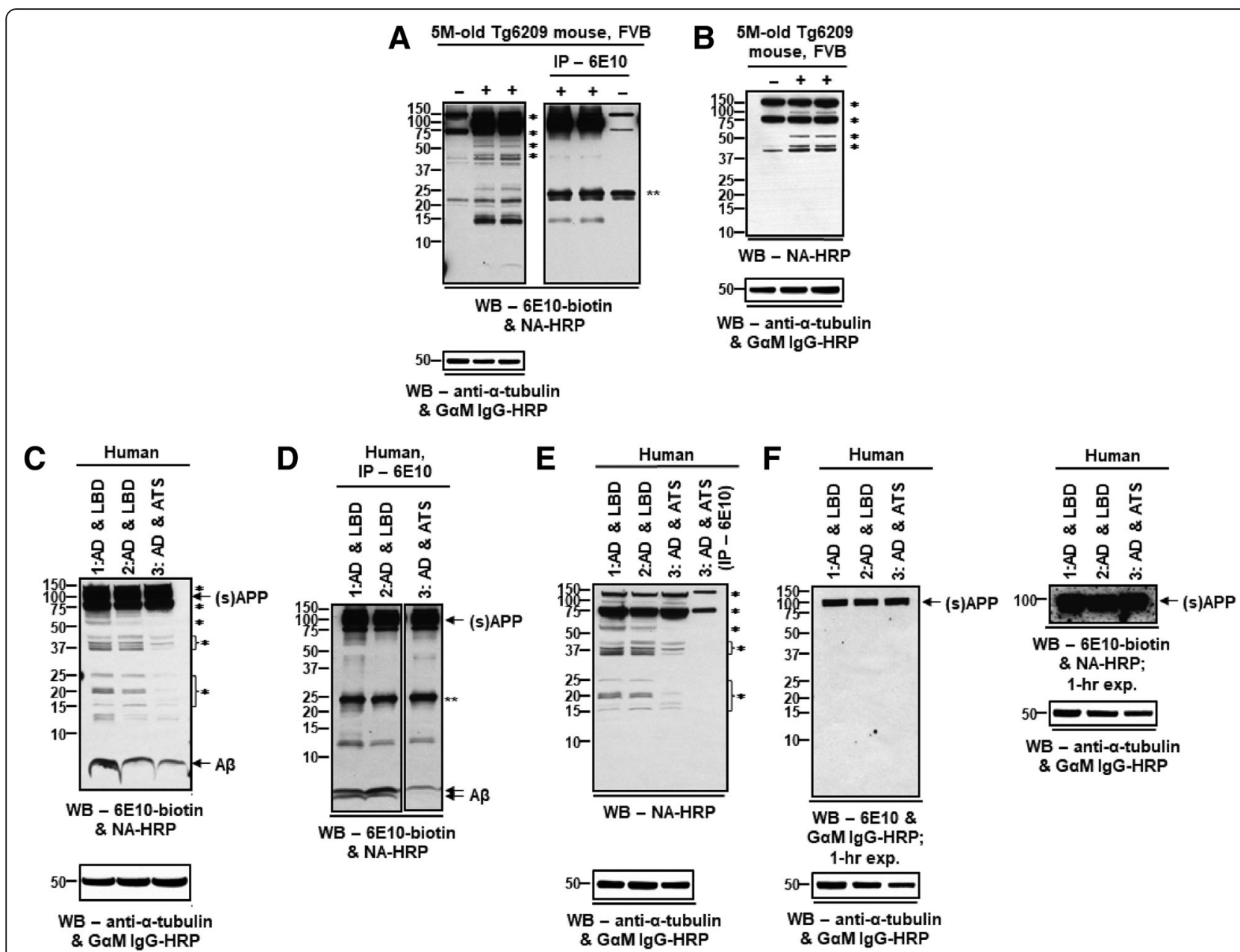

Fig. 1 Antibody-independent signals in blots developed using Neutravidin-HRP. a Left, Western blot of mouse-brain extracts, probed with biotinconjugated 6 E10 (6E10-biotin), followed by Neutravidin-HRP (NA-HRP) and chemiluminescence reagent. Right, samples immunoprecipitated with 6 E10 prior to blotting. Note bands marked by asterisks $\left(^{*}\right)$, which are eliminated $(\sim 46 \mathrm{kDa}, \sim 55 \mathrm{kDa})$ or diminished $(\sim 75 \mathrm{kDa}, \sim 150 \mathrm{kDa})$ when samples are immunoprecipitated prior to blotting. **, Protein G. b Blot of mouse-brain extracts processed with NA-HRP and chemiluminescence reagent, without exposure to antibody 6 E10. Note bands marked by $(*)$, which appear even in the absence of antibody. + , APP transgenic mice (line Tg6209); -, non-transgenic mouse. c Western blot of extracts from Alzheimer's disease (AD) brains, probed with 6E10-biotin, followed by NAHRP and chemiluminescence reagent. Lanes 1 and 2, brains had AD and Lewy body (LBD) pathology; lane 3, brain displayed AD pathology and atherosclerosis (ATS). Bands marked by asterisks $\left(^{*}\right)$ are also present in (e). (s)APP, full-length and/or a-secretase-cleaved, soluble N-terminal fragment of APP; A 3 , monomeric A. $\mathbf{d}$ Brain extracts in (c) immunoprecipitated with 6E10; blot processed as in (c). Compare pattern of bands in (c) and (d). (s)APP, AB, and a doublet at $\sim 12 \mathrm{kDa}$ are immunoprecipitated. ${ }^{* *}$, Protein G. e Blot processed with NA-HRP and chemiluminescence reagent, without exposure to antibody $6 \mathrm{E} 10$. IP, sample immunoprecipitated with $6 \mathrm{E} 10$; other lanes, samples prepared as in (c). Note that (s)APP, $\sim 12-\mathrm{kDa}$ doublet, and A $\beta$ bands, seen when blots are exposed to anti-APP/A $\beta$ antibody $6 \mathrm{E} 10$ (c), are absent here, and that immunoprecipitation eliminates or diminishes the non-specific bands $\left({ }^{*}\right)$. $\mathbf{f}$ Left, blot probed with unconjugated 6 E10 followed by goat-anti-mouse $\lg \mathrm{G}$ conjugated to HRP (GaM IgG-HRP), 1-h exposure. Only the (s)APP band is detectable. Right, (s)APP signal after 1-h exp. in blot probed using 6E10-biotin, followed by NA-HRP, for comparison. (Bottom panels accompanying Western blots show anti-a-tubulin loading controls (see Methods))

when we attempted to immunopurify $\mathrm{A} \beta$ species from brain lysates.

When brain lysates from hAPP-J20 transgenic mice were subjected to immunoaffinity purification using anti-A $\beta_{40 / 42}$-conjugated magnetic beads, and the eluate from the beads was then analyzed by Western blot, a single $\sim 55-\mathrm{kDa}$ band was revealed in blots probed using either 6E10 or the "oligomer-specific" antibody A11 [20]. Our initial interpretation of this finding was that this band represented an isolated $A \beta$ oligomer or an SDS-stable protein complex that contained $A \beta$. However, similar bands were detected by $6 \mathrm{E} 10$ and $\mathrm{A} 11$ when brain lysates from non-transgenic mice were subjected to the same immunoaffinity-purification protocol (Fig. 2a). As 6E10 is human-specific, the band revealed by this antibody after immunopurification of lysates from non-transgenic animals cannot represent an authentic APP metabolite. 
A

$17 \frac{\mathrm{IAC}-\alpha \mathrm{A} \beta_{40 / 42}}{\mathrm{M} \text {-old mouse, } \mathrm{C} 57 \mathrm{BL} / 6 \mathrm{~J}}$

은 ్ㅜㄱ

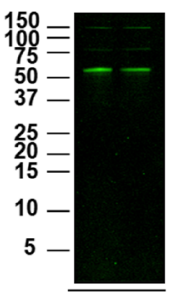

옫 욕

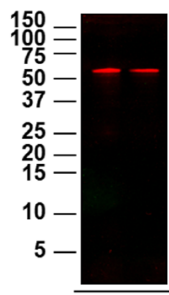

WB-6E10-biotin $\overline{\text { WB-A11 }}$
B

IAC

ID $\alpha A \beta_{40 / 42}$

C

IAC

$\alpha A \beta_{40 / 42}$

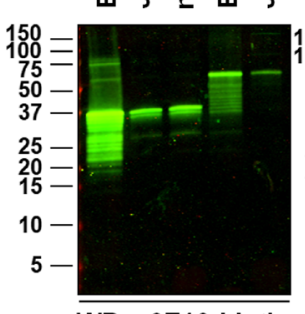

WB-6E10-biotin

Recomb Native

13M-old mouse, C57BL/6J

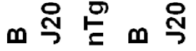

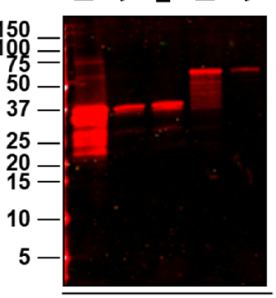

WB - A11

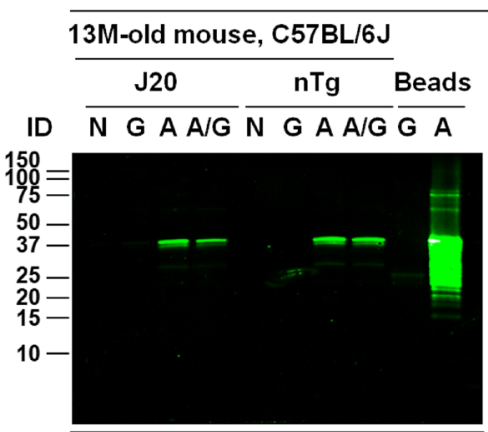

WB -6E10-biotin

D

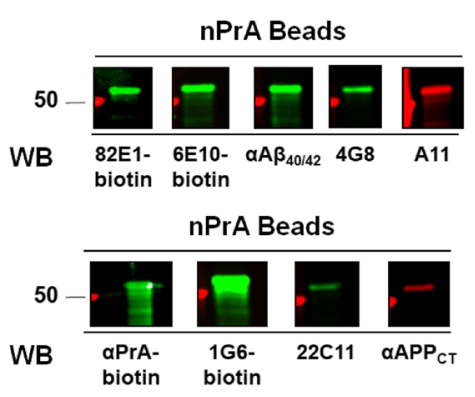

13M-old mouse, C57BL/6J

J20 nTg Beads
$\overline{N G A A / G} \overline{N G A A / G G A}$

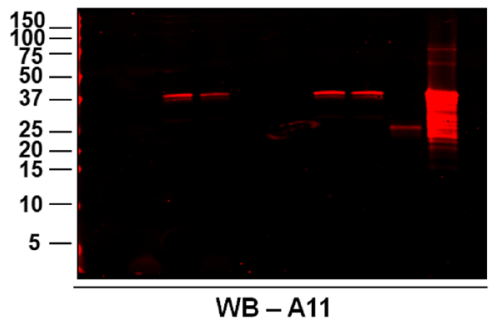

E

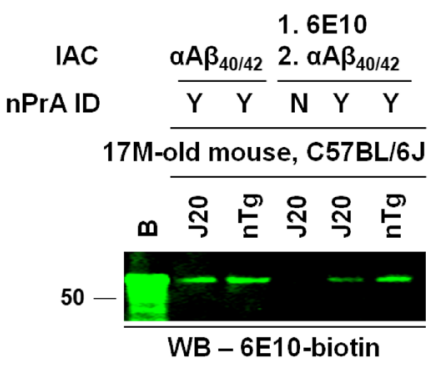

Fig. 2 (See legend on next page.) 
(See figure on previous page.)

Fig. 2 Protein A contamination leads to artefactual bands during immunoaffinity purification. a Similar bands are detected by Western blot after immunoaffinity purification (anti-A $\beta_{40 / 42}$ immunoaffinity matrix) of brain lysates from hAPP-J20 (J20) or non-transgenic (nTg) mice. Left, blot probed with 6E10-biotin, followed by IR-conjugated Neutravidin; right, blot probed with A11 followed by IR-conjugated goat-anti-rabbit lgG. Because monoclonal antibody 6 E10 does not recognize mouse AB/APP, bands cannot represent genuine 6 E10 immunoreactivity. b Molecular weights of bands detected by Western blot depend upon the source of Protein A used for immunodepletion. Brain lysates from J20 or nTg mice were depleted of endogenous immunoglobulins using either recombinant (recomb) or native Protein A (PrA), conjugated to Sepharose beads, and then subjected to anti-A $\beta_{40 / 42}$ immunoaffinity purification. Eluates were analyzed in Western blots probed with $6 \mathrm{E} 10$ (left, green) or A11 (right, red). "B" marks material recovered after boiling of Protein A-conjugated Sepharose beads. c Bands present only in samples exposed to Protein $A$. Brain lysates from $J 20$ or $n T g$ mice underwent anti-A $\beta_{40 / 42}$ immunoaffinity purification, either without prior depletion of endogenous immunoglobulins (N) or following depletion using Protein A (recombinant) and/or Protein G. Western blots of the eluates from the anti-A $\beta_{40 / 42}$ matrix, probed with 6E10 (left, green) or A11 (right, red). "Beads" marks material recovered after boiling of Protein A- or Protein G- conjugated Sepharose beads. $\mathbf{d}$ Multiple antibodies react with denatured Protein A. Protein A-conjugated Sepharose beads were boiled in SDS-PAGE loading buffer, and recovered material was subjected to SDS-PAGE and Western blot. Blots were probed using a panel of antibodies (Table 1). e Brain lysates from J20 or nTg mice were subjected to single-step (anti-A $\beta_{40 / 42}$ ) or sequential (6E10 followed by anti-A $\beta_{40 / 42}$ ) immunoaffinity purification. IAC, immunoaffinity capture. nPrA ID, lysate immunodepleted using (native) Protein A-Sepharose prior to immunoaffinity purification; $Y$, yes; $N$, no. Blots probed with 6E10-biotin, followed by IR-conjugated Neutravidin. "B," material recovered after boiling Protein A-Sepharose

We suspected that the $\sim 55-\mathrm{kDa}$ band might represent Protein A contamination, due to incidental observations in earlier, unrelated experiments where a similarly migrating band was seen in various blots from lysates depleted using native protein A (as used for the lysates in the immunopurification experiments illustrated in Fig. 2a) but not recombinant Protein A or Protein G. We therefore prepared a new series of brain lysates, immunodepleted with native Protein A (nProtA), recombinant Protein A (rProtA), and/or Protein G. When subjected to the immunopurification protocol followed by Western blot analysis using 6E10 or A11, the lysates depleted with rProtA yielded an $\sim 37-\mathrm{kDa}$ band, rather than the $\sim 55-\mathrm{kDa}$ band seen after "purification" of lysates depleted using nProtA (Fig. 2b). No 6E10- or A11-binding species were seen after purification of lysates depleted with only Protein G (Fig. 2c).

Multiple antibodies (Table 1) that we use in our studies of APP and its metabolites were found to bind to denatured Protein A (Fig. 2d).

Finally, we subjected brain lysates to a sequential immunopurification protocol that has been reported to yield $A \beta$ oligomers [21]. Lysate was first applied to $6 E 10$-conjugated magnetic beads, then the eluate from these beads was applied to anti-A $\beta_{40 / 42}$-conjugated beads. Probing with 6E10, Western blots of the eluate from these beads showed a single, prominent band at $55 \mathrm{kDa}$ when using lysates that had been immunodepleted using (native) Protein A-Sepharose beads prior to immunoaffinity purification. This band was observed in lysates from both transgenic and non-transgenic animals but was absent in lysates that had not been exposed to Protein A (Fig. 2e).

We conclude that the 6E10- and A11-positive bands represent binding of the antibodies to Protein A that shed from the Sepharose beads during the depletion step and carried through the immunoaffinity purification steps (Fig. 3). We were initially surprised that Protein A would be bound by, and then eluted from, the antibodyconjugated beads; however, in addition to binding the Fc region, Protein A has been shown to bind the Fab region of some mouse monoclonal antibodies, and this binding is disrupted at low $\mathrm{pH}$, such as that used for elution in our protocol [22, 23].

\section{Discussion}

Critical to the correct interpretation of Western blots is the ability to determine which bands represent the target proteins and which are artefacts. Identification of the correct bands can be especially challenging when the molecular weights of the target species are uncertain, which is often the case when studying abnormal, disease-associated protein aggregation or cleavage. We here describe two antibody-independent artefacts that may cloud the interpretation of immunoblotting experiments: i) the detection of endogenous biotinylated proteins when avidin-biotin systems are used for antibody detection, and ii) the introduction of exogenous proteins-Protein A, in the example illustrated here-that bind detection antibodies.

The potential interference of endogenous biotin in immunohistochemistry [24, 25] and immunoblotting [11-13] has been recognized for decades. Indeed, the direct binding of labeled avidin derivatives to protein blots is used to study endogenous biotinylated proteins $[26,27]$. The brain has been reported to be one of the tissues with relatively high levels of endogenous biotin [24], so perhaps it should not be surprising that we found spurious bands due to endogenous biotin in our Western blots. But what was surprising-and what initially led us to believe that these bands represented actual 6E10-immunoreactive $\mathrm{APP} / \mathrm{A} \beta$-was the dramatic difference between $\operatorname{Tg} 6209$ mice, which overexpress wild-type human APP, and non-transgenic animals in the expression of several of these bands. However, it should be noted that the APP-transgene-dependent 


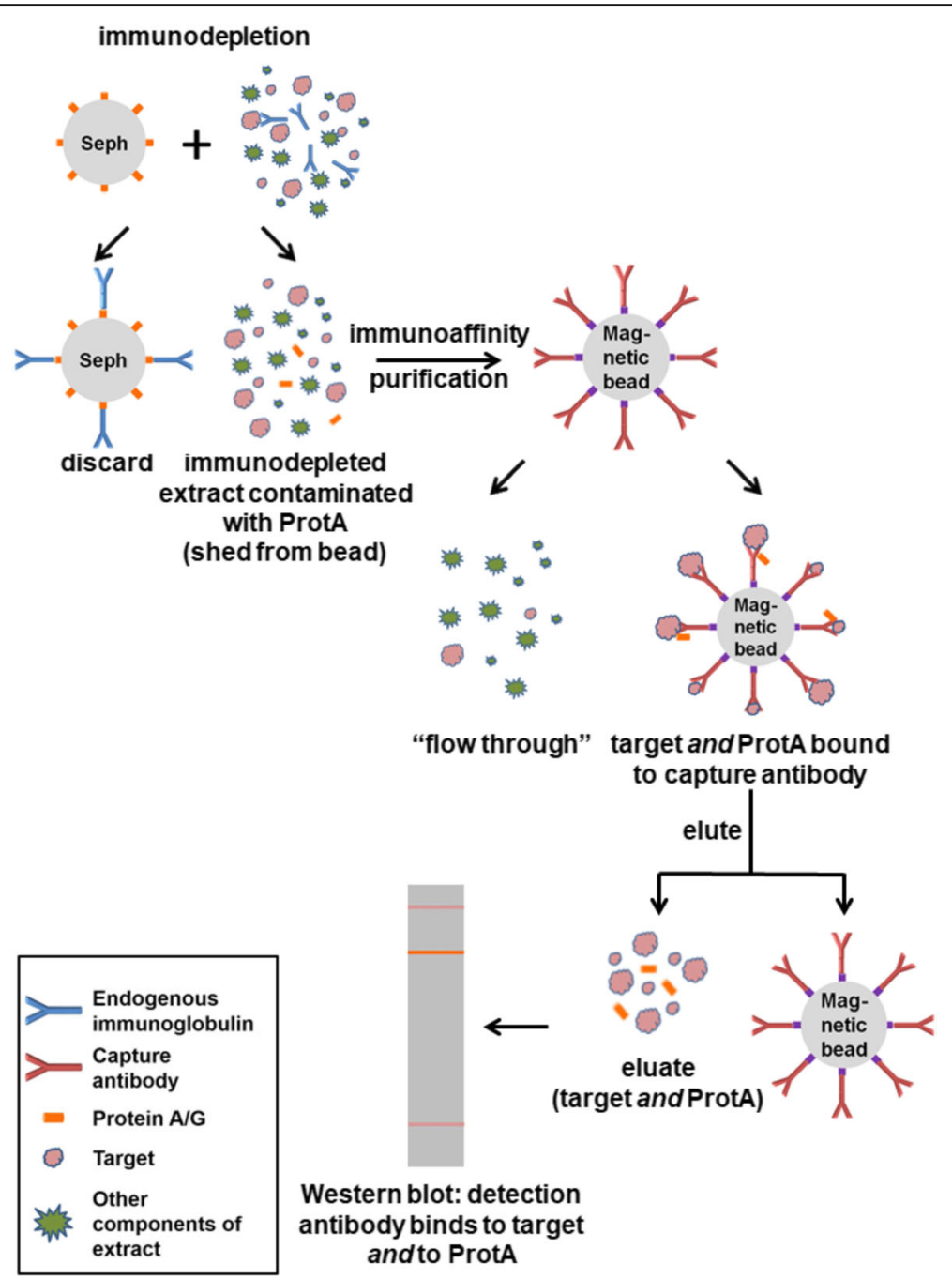

Fig. 3 Diagram illustrating genesis of Protein A artefact in immunoaffinity purification procedure. Brain lysates were depleted of endogenous immunoglobulins using Protein A-conjugated Sepharose beads. During this step, some Protein A shed from the beads and contaminated the brain lysate. Upon exposure to the immunoaffinity matrix, some of the Protein A bound to the Fab region of the immobilized antibodies. This Protein A was then eluted from the matrix by the low pH elution buffer used to recover the target species. During subsequent Western blotting of the eluate from the antibody-conjugated magnetic beads, the denatured Protein A was still able to bind detection antibody

expression of biotinylated proteins seen in brain lysates from Tg6209 mice was not seen in Tg2576 mice [28], which overexpress human APP with the AD-linked "Swedish" mutation. In addition to carrying different APP transgenes, the two lines are maintained on different genetic backgrounds-FVB for Tg6209 and B6SJL for $\operatorname{Tg} 2576$.

We did not seek to identify the molecular species giving rise to the antibody-independent, Neutravidindependent bands in our blots, although it should be noted that carboxylases are probably the best studied biotinylated proteins, and the prominent bands at $\sim 75$ $\mathrm{kDa}$ and $\sim 125-150 \mathrm{kDa}$ in both transgenic and non-transgenic mice and in humans might represent $\beta$-methylcrotonyl-CoA carboxylase $(72 \mathrm{kDa})$ and/or
propionyl-CoA-carboxylase $(74 \mathrm{kDa})$ and pyruvate carboxylase $(128 \mathrm{kDa})$ [27].

We also show that Protein A-shed from beads added to deplete lysates of endogenous immunoglobulinsbound to, and was eluted from, immunoaffinity matrices designed to capture APP and/or A $\beta$. This Protein A then bound detection antibodies when the immunoaffinity eluates were analyzed by Western blot. Although Protein $\mathrm{G}$ has also been reported to bind to Fab [22, 29], under our experimental conditions, Protein G did not cause a problem similar to that which we encountered when using Protein A. We do not know why we found these differences, but we speculate that there may have been less shedding of Protein G from the Sepharose beads or that the Protein G did not have as strong an affinity as 
Protein A for the antibodies used in our immunoaffinity purifications. At this time, we recommend that a decision as to whether to use Protein A or Protein G in any particular experiment be made empirically.

Much attention has been paid to the potential for poorly-characterized antibodies to lead to misleading results $[9,10,30]$. However, as shown here, antibody-independent artefacts may also occur when antibodies are used to detect or isolate other proteins. One way to monitor such artefacts is to include an "irrelevant" antibody as an experimental control (e.g., running a parallel protocol in which the antibody directed against the target of interest is replaced by a non-specific antibody). In the past, when laboratories generated their own polyclonal antibodies, it was standard practice to include pre-immune serum as a control. With the current dependence on commercial antibodies, it may not be possible to obtain pre-immune serum from the animal(s) that generated the "specific" antibodies, but normal sera or immunoglobulins from the same species should be readily available. When using monoclonal antibodieseven those with validated specificity-controls should include a non-specific immunoglobulin, preferably of the same isotype. As our studies illustrate, it is not sufficient to include as controls samples from animals known to lack the target protein, since bands attributable to endogenous biotinylated proteins can be seen in brain lysates from transgenic animals but not from nontransgenic mice (as seen in our experiments using the Tg6209 line of APP transgenic mice). Although the use of an "irrelevant antibody" control will not reveal the exact source of the artefact, this strategy is, to the authors' knowledge, the most efficient way to detect artefactual differences between experimental and control groups.

\section{Additional file}

Additional file 1: Figure S1. Survey of methodological controls in immunocapture and immunoblotting studies. (PDF 143 kb) protein fragment; Tris-HCl: Tris(hydroxymethyl)aminomethane-hydrochloric acid; Triton X-100: Polyethylene glycol p-(1,1,3,3-tetramethylbutyl)-phenyl ether; v/v: Volume/volume; w/v: Weight/volume; WB: Western blotting

\section{Acknowledgements}

The authors thank Drs. Pritam Das and Charles Glabe for providing antibodies.

\section{Funding}

This study, including experimental design, data collection, analysis and interpretation, and manuscript preparation, is supported by NIH RC1AG35870 and R01-NS33249 to KHA.

\section{Availability of Data and Materials}

All data generated or analyzed during this study are included in this published article.

\section{Authors' Contributions}

M.K.O.G., S.L.S. and K.R.Z. conceived the experiments, M.K.O.G. and S.L.S. performed the experiments and collected data, M.K.O.G., S.L.S., P.L. and K.R.Z. analyzed and interpreted data. K.H.A. and K.R.Z. supervised this study, and all authors contributed to writing and approving the manuscript.

\section{Ethics Approval and Consent to Participate}

The use of de-identified human brain tissue, obtained at autopsy, was reviewed and approved by the Research \& Development Committee (RDS) and Safety Committee (SRS) of the Minneapolis Veterans Administration Medical Center. All studies involving mice were conducted in full accordance with the guidelines of the Association for Assessment and Accreditation of Laboratory Animal Care (AAALAC) and approved by the Institutional Animal Care and Use Committee (IACUC) at the University of Minnesota (approval \# 1202A09927).

\section{Consent for Publication}

Not applicable.

\section{Competing Interests}

The authors declare that they have no competing interests.

\section{Publisher's Note}

Springer Nature remains neutral with regard to jurisdictional claims in published maps and institutional affiliations.

\section{Author details}

${ }^{1}$ Departments of Neurology, University of Minnesota, Minneapolis, MN 55455 USA. ${ }^{2}$ Departments of Neuroscience, University of Minnesota, Minneapolis, MN 55455, USA. ${ }^{3}$ N. Bud Grossman Center for Memory Research and Care, University of Minnesota, Minneapolis, MN 55455, USA. ${ }^{4}$ GRECC, VA Medical Center, Minneapolis, MN 55417, USA. ${ }^{5}$ Present address: Department of Experimental and Clinical Pharmacology, University of Minnesota, Minneapolis, MN 55455, USA. ${ }^{6}$ Present address: University of Wisconsin Madison, Madison, WI 53705, USA.

Received: 26 October 2018 Accepted: 8 April 2019

Published online: 18 April 2019

\section{References}

1. Prinz F, Schlange T, Asadullah K. Believe it or not: how much can we rely on published data on potential drug targets? Nat Rev Drug Discov. 2011;10(9):712.

2. Begley CG, Ellis LM. Drug development: raise standards for preclinical cancer research. Nature. 2012:483(7391):531-3.

3. Baker M. 1,500 scientists lift the lid on reproducibility. Nature. 2016; 533(7604):452-4.

4. Begley CG, loannidis JP. Reproducibility in science: improving the standard for basic and preclinical research. Circ Res. 2015;116(1):116-26.

5. Drucker DJ. Never waste a good crisis: confronting reproducibility in translational research. Cell Metab. 2016;24(3):348-60.

6. Sudhof TC. Truth in science publishing: a personal perspective. PLoS Biol. 2016;14(8):e1002547. 
7. Amrhein $V$, Korner-Nievergelt $F$, Roth $T$. The earth is flat $(p>0.05)$ : significance thresholds and the crisis of unreplicable research. PeerJ. 2017;5:e3544.

8. Hunter P. The reproducibility "crisis": reaction to replication crisis should not stifle innovation. EMBO Rep. 2017;18(9):1493-6.

9. Baker M. Reproducibility crisis: blame it on the antibodies. Nature. 2015; 521(7552):274-6.

10. Bradbury A, Pluckthun A. Reproducibility: standardize antibodies used in research. Nature. 2015:518(7537):27-9.

11. Praul CA, Brubaker KD, Leach RM, Gay CV. Detection of endogenous biotincontaining proteins in bone and cartilage cells with streptavidin systems. Biochem Biophys Res Commun. 1998;247(2):312-4.

12. Vaitaitis GM, Sanderson RJ, Kimble EJ, Elkins ND, Flores SC. Modification of enzyme-conjugated streptavidin-biotin western blot technique to avoid detection of endogenous biotin-containing proteins. Biotechniques. 1999; 26(5):854-8.

13. Banks RE, Craven RA, Harnden PA, Selby PJ. Use of a sensitive EnVision + -based detection system for Western blotting: avoidance of streptavidin binding to endogenous biotin and biotin-containing proteins in kidney and other tissues. Proteomics. 2003;3(4):558-61.

14. Sherman MA, Lesne SE. Detecting abeta*56 oligomers in brain tissues. Methods Mol Biol. 2011;670:45-56.

15. Hsiao KK, Borchelt DR, Olson K, Johannsdottir R, Kitt C, Yunis W, Xu S, Eckman C, Younkin S, Price D, et al. Age-related CNS disorder and early death in transgenic FVB/N mice overexpressing Alzheimer amyloid precursor proteins. Neuron. 1995:15(5):1203-18.

16. Mucke L, Masliah E, Yu GQ, Mallory M, Rockenstein EM, Tatsuno G, Hu K, Kholodenko D, Johnson-Wood K, McConlogue L. High-level neuronal expression of abeta 1-42 in wild-type human amyloid protein precursor transgenic mice: synaptotoxicity without plaque formation. J Neurosci. 2000; 20(11):4050-8.

17. Jankowsky $\mathrm{J}$, Zheng $\mathrm{H}$. Practical considerations for choosing a mouse model of Alzheimer's disease. Mol Neurodegener. 2017;12(1):89.

18. Sasaguri H, Nilsson P, Hashimoto S, Nagata K, Saito T, De Strooper B, Hardy J, Vassar R, Winblad B, Saido TC. APP mouse models for Alzheimer's disease preclinical studies. EMBO J. 2017;36(17):2473-87.

19. Mc Donald JM, O'Malley TT, Liu W, Mably AJ, Brinkmalm G, Portelius E, Wittbold WM 3rd, Frosch MP, Walsh DM. The aqueous phase of Alzheimer's disease brain contains assemblies built from approximately 4 and approximately 7 kDa Abeta species. Alzheimers Dement. 2015; 11(11):1286-305.

20. Kayed R, Head E, Thompson JL, Mclntire TM, Milton SC, Cotman CW, Glabe CG. Common structure of soluble amyloid oligomers implies common mechanism of pathogenesis. Science. 2003;300(5618):486-9.

21. Amar F, Sherman MA, Rush T, Larson M, Boyle G, Chang L, Gotz J, Buisson A, Lesne SE. The amyloid-beta oligomer Abeta*56 induces specific alterations in neuronal signaling that lead to tau phosphorylation and aggregation. Sci Signal. 2017;10(478). https://doi.org/10.1126/scisignal.aal2021.

22. Young WW Jr, Tamura Y, Wolock DM, Fox JW. Staphylococcal Protein A binding to the Fab fragments of mouse monoclonal antibodies. J Immunol. 1984;133(6):3163-6.

23. Ibrahim S, Kaartinen M, Seppala I, Matoso-Ferreira A, Makela O. The alternative binding site for Protein $A$ in the Fab fragment of immunoglobulins. Scand J Immunol. 1993;37(2):257-64.

24. Wang $H$, Pevsner J. Detection of endogenous biotin in various tissues: novel functions in the hippocampus and implications for its use in avidin-biotin technology. Cell Tissue Res. 1999;296(3):511-6.

25. Ziegler R, Engler DL, Davis NT. Biotin-containing proteins of the insect nervous system, a potential source of interference with immunocytochemical localization procedures. Insect Biochem Mol Biol. 1995;25(5):569-74.

26. Haneji T, Koide SS. Transblot identification of biotin-containing proteins in rat liver. Anal Biochem. 1989;177(1):57-61.

27. Pacheco-Alvarez D, Solorzano-Vargas RS, Gravel RA, Cervantes-Roldan R, Velazquez A, Leon-Del-Rio A. Paradoxical regulation of biotin utilization in brain and liver and implications for inherited multiple carboxylase deficiency. J Biol Chem. 2004;279(50):52312-8.

28. Hsiao K, Chapman P, Nilsen S, Eckman C, Harigaya Y, Younkin S, Yang F, Cole G. Correlative memory deficits, Abeta elevation, and amyloid plaques in transgenic mice. Science. 1996;274(5284):99-102.
29. Erntell M, Myhre EB, Sjobring U, Bjorck L. Streptococcal protein G has affinity for both Fab- and Fc-fragments of human IgG. Mol Immunol. 1988;25(2):121-6.

30. Uhlen M, Bandrowski A, Carr S, Edwards A, Ellenberg J, Lundberg E, Rimm DL, Rodriguez H, Hiltke T, Snyder M, et al. A proposal for validation of antibodies. Nat Methods. 2016;13(10):823-7.

\section{Ready to submit your research? Choose BMC and benefit from:}

- fast, convenient online submission

- thorough peer review by experienced researchers in your field

- rapid publication on acceptance

- support for research data, including large and complex data types

- gold Open Access which fosters wider collaboration and increased citations

- maximum visibility for your research: over $100 \mathrm{M}$ website views per year

At BMC, research is always in progress.

Learn more biomedcentral.com/submissions 